\title{
PEMBELAJARAN MATEMATIKA DENGAN MENGGUNAKAN PENDEKATAN OPEN-ENDED UNTUK MENINGKATKAN KEMAMPUAN BERFIKIR KREATIF SISWA
}

\author{
Anwar Sadat ${ }^{1}$, Muhammad Iqbal Harisuddin ${ }^{2}$, Ifung Oktavian ${ }^{3}$ \\ 1,2,3 Jurusan Pendidikan Matematika STKIP Subang \\ ${ }^{1}$ mocsadatanwar@gmail.com, ${ }^{2}$ akyssa.2@gmail.com, ${ }^{3}$ ifung@gmail.com
}

\begin{abstract}
ABSTRAK
Penelitian ini bertujuan untuk menelaah keefektifan pembelajaran dengan pendekatan open-ended dibandingkan dengan penerapan pembelajaran konvensional terhadap peningkatan kemampuan berfikir kreatif siswa. Selain itu, dianalisis pula tentang sikap siswa terhadap penerapan pembelajaran matematika dengan menggunakan pendekatan open-ended. Jenis penelitian yang dilakukan adalah penelitian kuasi eksperimen dengan sampel penelitian terdiri dari 64 siswa kelas VIII yang berasal dari dua kelas di MTs Negeri I Subang. Kedua kelas diberikan pretes dan postes kemampuan berfikir kreatif, dan diberi angket sikap siswa terhadap penerapan pembelajaran dengan pendekatan openended. Hipotesis penelitian diuji dengan menggunakan uji parametrik dan uji non-parametrik. Hasil penelitian menyatakan bahwa: (1) peningkatan kemampuan berfikir kreatif siswa kelas eksperimen lebih baik daripada siswa kelas kontrol; (2) Sebagian besar siswa memberikan sikap positif terhadap pembelajaran matematika yang menggunakan pendekatan open-ended.
\end{abstract}

Kata kunci: Berfikir Kreatif, Open-ended, Sikap

\begin{abstract}
This study aims to examine the effectiveness of learning with an open-ended approach compared to the application of conventional learning to improving students' creative thinking abilities. In addition, it also analyzed about students' attitudes towards the application of mathematics learning using the open-ended approach. This type of research is a quasiexperimental study with a sample of 64 class VIII students from two classes in MTs Negeri I Subang. Both classes were given pretest and posttest ability to think creatively, and were given questionnaires for student attitudes towards the application of learning with an openended approach. The research hypothesis was tested using parametric tests and nonparametric tests. The results of the study stated that: (1) the increase in the creative thinking ability of the experimental class students was better than the control class students; (2) Most students give positive attitude towards learning mathematics using the open-ended approach.
\end{abstract}

Keywords: Creative Thinking, Open-ended, Attitude

\section{PENDAHULUAN}

Matematika merupakan dasar dari perkembangan ilmu pengetahuan dan teknologi yang sangat penting dalam kehidupan sehari-hari. Matematika juga ilmu yang memegang peranan penting dalam perkembangan ilmu-ilmu lain. Oleh karena itu, sesuai apa yang diungkapkan oleh Sumarmo (Ranti, 2014)" mathematics as a human activity", maksudnya adalah bahwa matematika terlibat dalam kehidupan setiap manusia, baik dalam perkara sedehana dan bersifat rutin, maupun yang bersifat komfleks. Karena itu, matematika menjadi 
mata pelajaran wajib dalam setiap jenjang pendidikan, sehingga diharapankan mereka mempelajari bagaimana berpikir logis, analitis, sistematis, kritis dan kreatif serta mampu bekerja sama dengan masyarakat yang luas. Salah satu pelajaran matematika di sekolah agar siswa memiliki kemampuan mengembangkan dan menggunakan ide atau gagasan adalah dengan menggunakan simbol, tabel, diagram dan media lainnya. Namun, dalam pelaksanaannya banyak hambatan yang ditemui, sebagai contoh, siswa cenderung tidak suka dengan pelajaran matematika. Banyak siswa yang mengalami kesulitan dalam mengerjakan soal-soal matematika, dalam pembelajaran sering terjadi interaksi yang lemah antara siswa dan pendidik, sehingga kemampuan siswa kurang telatih dan suasana pembelajaran menjadi membosankan, selain itu siswa tidak bisa mengkomunikasikan gagasan yang mereka pahami. Sebenarnya tidak sulit dalam pembelajaran matematika jika siswa memahami konsep dengan benar. Pemahaman konsep yang tepat dalam pembelajaran matematika akan membuat siswa lebih aktif, kreatif, percaya diri, dan mudah mengaplikasikan dalam soal.

James dan James dalam suherman (2003:16) mengatakan bahwa matematika adalah ilmu tentang logika mengenai bentuk susunan, besaran, dan konsep-konsep yang berhubungan satu sama lain dengan yang lainnya dengan jumlah yang banyak yang terbagi dalam tiga bidang yaitu aljabar, analisis, dan geometri. Oleh karena itu, untuk setiap materi siswa di harapkan benar-benar menguasai konsep yang di berikan konsep karena konsep tersebut akan digunakan untuk mempelajari materi berikutnya.

Menurut Masykur (2007:34) hasil penelitian di Indonesia, ditemukan bahwa tingkat penguasaan peserta didik dalam matematika pada semua jenjang pendidikan masih sekitar $34 \%$ anggapan masyarakat dikalangan pelajar, matematika masih merupan mata pelajaran sulit membingungkan untuk sebagian besar pelajaran. Meskipun demikian, semua orang harus mempelajari matematika karena merupakan saran untuk memecahkan kehidupan sehari-hari

Rendahnya minat belajar siswa tidak hanya karena kesalahan siswa, tetapi juga disebabkan penyampaian guru yang kurang menarik. Pelaksanaan pembelajaran di sekolah pada umumnya masih berpusat pada guru. Siswa kurang berperan aktif didalamnya, sehingga tujuan pembelaran dan kegiatan yang akan dilakukan oleh siswa pada proses pembelajaran ini banyak dipengaruhi oleh guru. Guru lebih dominan dalam pembelajaran, sehingga keaktifan siswa di kelas manjadi kurang. Dewasa ini guru dituntut kreatif dalam menggukan pendekatan/metode mengajar yang sesuai dengan materi yang diajarkan. Menurut Slameto (2003:65), metode mengajar adalah suatu cara yang harus dilalui di dalam 
mengajar. Metode mengajar merupakan salah satu faktor eksternal yang mempengaruhi hasil belajar siswa. Metode mengajar guru yang kurang baik akan mempengaruhi belajar siswa yang tidak baik pula, sehingga hal tersebut akan membuat siswa menjadi kurang senang terhadap pelajaran. Akibatnya siswa menjadi malas untuk belajar sehingga hasil belajar siswa pun menjadi rendah. Agar siswa dapat belajar dengan baik dan memperoleh hasil belajar yang baik, maka pedidik yang mengajar harus memikirkan metode pembelajaran yang tepat, efisien, dan efektif mungkin. Oleh karena itu dibutuhkan pendidik yang memiliki progresif dan berani dalam mencoba metode baru yang dapat membatu siswa dalam meningkatkan kegiatan belajar.

Salah satu pendekatan yang dapat digunakan untuk mengetahui kemampuan berfikir kreatif siswa adalah pendekatan open ended. Pendekatan open-ended memberikan siswa kebebasan dalam menginvestigasi berbagai strategi yang diyakininya untuk menyelsaikan suatu masalah. Suherman (2003:124) mengemukakan bahwa yang menjadi pokok pikiran pembelajaran dengan pendekatan open-ended adalah pembelajaran yang membangun kegiatan interaktif anatara matematika dan siswa sehingga mengundang siswa untuk menjawab permasalahan melalui beberapa strategi.

Berdasarkan latar belakang yang telah dipaparkan, penulis tertarik untuk melakukan penelitian mengenai implementasi pembelajaran matematika dengan menggunakan pendekatan open-ended untuk meningkatkan kemampuan berfikir kreatif siswa. Penelitian ini berfokus pada masalah: (1) Apakah peningkatan kemampuan berfikir kreatif siswa MTs yang mendapat pembelajaran dengan pendekatan open-ended lebih baik dibandingkan dengan siswa yang mendapat pembelajaran konvensional? (2) Bagaimana sikap siswa terhadap pembelajaran matematika dengan menggunakan pendekatan open-ended?

\section{METODE PENELITIAN}

Penelitian ini menggunakan metode kuasi eksperimen dengan desain kelompok kontrol pretes-postes. Penelitian dilaksanakan di MTs Negeri I Kabupaten Subang semester ganjil tahun ajaran 2019/2020 dengan populasi seluruh siswa kelas VIII dan digunakan dua kelas sebagai sampel dari sejumlah kelas VIII yang ada secara purposif.

Penelitian ini dilakukan dalam beberapa langkah, langkah pertama berkaitan dengan persiapan pembuatan instrumen penelitian dan bahan ajar. Langkah kedua adalah proses pelaksanaan penelitian, dengan tahapan memberikan soal pretes kepada siswa kelas eksperimen dan kelas kontrol, memberi pembelajaran dengan menggunakan pendekatan 
open-ended untuk kelas eksperimen, sedangkan kelas kontrol menggunakan pembelajaran konvensional, memberikan soal postes untuk kedua kelas, dan memberikan angket skala sikap kepada kelas eksperimen. Langkah ketiga melakukan analisis peningkatan kemampuan berfikir kreatif yang dicapai siswa kedua kelas baik siswa yang memperoleh pembelajaran dengan pendekatan open-ended maupun yang memperoleh pembelajaran konvensional. Teknik analisis data dilakukan atas data kuantitatif dan data kualitatif yang dikuantitatifkan. Langkah keempat menyiapkan laporan hasil penelitian.

\section{HASIL DAN PEMBAHASAN}

\section{Kemampuan berfikir kreatif}

Peningkatan kemampuan berfikir kreatif siswa dalam penelitian ini, dianalisis dengan mengolah data hasil pretes, postes dan $N$-gain. Pretes diberikan kepada kedua kelas untuk mengetahui bagaimana kemampuan awal berfikir kreatif siswa, sedangkan postes diberikan untuk mengetahui kemampuan akhir berfikir kreatif siswa. Berikut ini disajikan statistik deskriptif dari data hasil pretes dan postes

Tabel 1 Data Statistik Skor Kemampuan Berfikir Kreatif

\begin{tabular}{lccc}
\hline & & Statistik Pretes & Statistik Postes \\
\hline \multirow{4}{*}{ Kelas Eksperimen } & $\mathrm{N}$ & 32 & 32 \\
& $X_{\max }$ & 10 & 24 \\
Kelas Kontrol & $X_{\min }$ & 2 & 13 \\
& $\bar{X}$ & 4.906 & 18.23 \\
& $\mathrm{~S}$ & 2.247 & 2.750 \\
& $\mathrm{~N}$ & 32 & 32 \\
& $X_{\max }$ & 9 & 23 \\
& $X_{\min }$ & 2 & 10 \\
& $\bar{X}$ & 4.125 & 15.59 \\
\hline Skor Maksimal Ideal & $\mathrm{S}$ & 1.728 & 3.374 \\
\hline
\end{tabular}

Pengujian hipotesis statistik menggunakan bantuan software minitab 18 for windows sebagai berikut.

Hasil uji normalitas data pretes disajikan dalam Tabel berikut.

Tabel 2 Hasil Uji Normalitas Data Pretes

\begin{tabular}{ccc}
\hline No & Kelas & P-Value \\
\hline 1 & Eksperimen & 0.072 \\
2 & Kontrol & 0.059 \\
\hline
\end{tabular}

Berdasarkan hasil uji normalitas data pretes kedua kelas, disimpulkan bahwa data hasil pretes kelas eksperimen dan kelas kontrol berdistribusi normal ( $P$-Value. $>0.05)$. Oleh karena kedua data berdistribusi normal, maka selanjutnya dilakukan uji homogenitas 
variansi kedua data. Uji homogenitas dilakukan untuk mengetahui variansi dari kelas eksperimen dan kelas kontrol apakah memiliki variansi yang sama atau beda. Untuk menghitung homogenitas variansi dari kedua kelas tersebut digunakan uji-F (Levene Statistic) yang disajikan pada Tabel 3

Tabel 3 Hasil Uji Homogenitas Varians Pretes Kemampuan Berfikir Kreatif Kelas Eksperimen dan Kelas Kontrol

\begin{tabular}{ccc}
\hline No & Uji Statistik & P-Value \\
\hline 1 & F-Test & 0.0815 \\
\hline
\end{tabular}

Berdasarkan Tabel 3 diperoleh nilai P-Value $=0.088$. Karena nilai P-Value $>0.05$, maka data hasil tes awal (pretes) kelas eksperimen dan kelas kontrol adalah homogen. Karena data homogen, uji statistik selanjutnya adalah uji t. Hasil uji t disajikan dalam Tabel berikut.

Tabel 4 Hasil Uji Perbedaan Dua Rerata Pretes Kemampuan Berfikir Kreatif Siswa Kelas Eksperimen dan Kelas Kontrol

\begin{tabular}{ccc}
\hline No & Uji Statistik & P-Value \\
\hline 1 & t-tes & 0.104 \\
\hline
\end{tabular}

Berdasarkan Tabel 4 hasil uji perbedaan dua rerata dapat disimpulkan bahwa kelas eksperimen dan kelas kontrol memiliki kemampuan awal yang setara, dengan nilai P-Value $=0.104>0.05$. Hal ini menunjukan bahwa kemampuan awal berfikir kreatif siswa kelas eksperimen sama atau tidak terdapat perbedaan yang signifikan dengan kemampuan awal berfikir kreatif siswa kelas kontrol

Oleh karena hasil analisis data pretes menunjukkan bahwa kemampuan awal berfikir kreatif siswa kedua kelas berada pada level yang sama, maka untuk melihat perbedaan peningkatan kemampuan tersebut digunakan data hasil postes, data $N$-gain hanya akan digunakan untuk memberikan gambaran tentang bagaimana mutu peningkatan kemampuan berfikir kreatif siswa di kedua kelas.

Hasil uji normalitas data postes kedua kelas disajikan dalam Tebel berikut.

Tabel 5 Hasil Uji Normalitas Data Postes Kemampuan Berfikir Kreatif Siswa Kelas Eksperimen dan Kelas Kontrol

\begin{tabular}{ccc}
\hline No & Kelas & P-Value \\
\hline 1 & Eksperimen & 0.150 \\
2 & Kontrol & 0.122 \\
\hline
\end{tabular}

Berdasarkan Tabel 5, untuk kelas eksperimen diperoleh nilai P-Value $=0.150$. Karena nilai P-Value > 0.05, maka skor postes kemampuan berfikir kreatif kelas eksperimen 
berdistribusi normal. Begitu juga untuk kelas kontrol diperoleh nilai $\mathrm{P}-$ Value $=0.122$. karena nilai P-Value > 0.05, maka skor postes kemampuan berfikir kreatif kelas kontrol berdistribusi normal. Karena kedua jenis data berdistribusi normal, maka selanjutnya dilakukan uji homogenitas variansi (Levene Statistic). Hasil Uji Homogenitas disajikan dalam Tabel berikut.

Tabel 6 Hasil Uji Homogenitas Varians Skor Postes Kemampuan Berfikir Kreatif Kelas Eksperimen dan Kelas Kontrol

\begin{tabular}{ccc}
\hline No & Uji Statistik & P-Value \\
\hline 1 & F-Test & 0.240 \\
\hline
\end{tabular}

Berdasarkan Tabel 6 diperoleh nilai P-Value $=0.240>0.05$, sehingga varians kemampuan berfikir kreatif kelas eksperimen dan kelas kontrol adalah homogen. Karena varians kedua data homogen, uji statistik selanjutnya adalah uji t. Hasil uji t disajikan dalam Tabel berikut.

Tabel 7 Hasil Uji Perbedaan Dua Rerata Postes Kemampuan Berfikir Kreatif Siswa Kelas Eksperimen dan Kelas Kontrol

\begin{tabular}{ccc}
\hline No & Uji Statistik & P-Value \\
\hline 1 & t-tes & 0.000 \\
\hline
\end{tabular}

Berdasarkan Tabel 7 uji perbedaan dua rerata dapat disimpulkan bahwa nilai P-Value $(1$-tailed $)=0.000<0.05$, maka dapat disimpulkan bahwa $\mathrm{H}_{0}$ yang menyatakan tidak terdapat perbedaan kemampuan berfikir kreatif siswa kelas eksperimen dengan kemampuan berfikir kreatif kelas kontrol, ditolak. Artinya siswa yang memperoleh pembelajaran matematika dengan menggunakan pendekatan open-ended memiliki kemampuan perfikir kreatif yang lebih baik daripada siswa yang memperoleh pembelajaran konvensional.

\section{Analisis data N-gain pretes - postes}

Berikut adalah Hasil perhitungan data $N$-gain secara deskriptif disajikan dalam Tabel berikut.

Tabel 7 Data $N$-gain Kemampuan Berfikir Kreatif Siswa

\begin{tabular}{cccc}
\hline & $\mathrm{N}$ & Rerata $N$-gain & Kualifikasi \\
\hline Kelas Eksperimen & 32 & 0.672 & Sedang \\
Kelas Kontrol & 32 & 0.520 & Sedang \\
\hline
\end{tabular}

Analisis data N-Gain adalah analisis data yang dilakukan terhadap data peningkatan kemampuan berfikir kreatif siswa. Analisis ini dilakukan sejauh mana peningkatan kemampuan berfikir kreatif siswa setelah diberikan pembelajaran matematika dengan menggunakan pendekatan open-ended pada kelas eksperimen dan pembelajaran 
konvensioanl pada kelas kontrol. Untuk mengetahui bahwa kemampuan berfikir kreatif dapat meningkat secara signifikan dilakukan perhitungan data N-Gain

Uji normalitas data N-Gain menggunakan uji statistik Kolmogorov-Smirnov dapat dilihat pada Tabel berikut.

Tabel 8 Hasil Uji Normalitas N-Gain Kemampuan Berfikir Kreatif Kelas Eksperimen dan Kelas Kontrol

\begin{tabular}{ccc}
\hline No & Kelas & P-Value \\
\hline 1 & Eksperimen & 0.150 \\
2 & Kontrol & 0.150 \\
\hline
\end{tabular}

Berdasarkan Tabel 8 diperoleh hasil uji normalitas data N-gain dengan P-Value kelas eksperimen dan kelas kontrol adalah 0.150. karena nilai P-Value > 0.05, maka dapat disimpulkan bahwa data kedua kelas berdistribusi normal. Karena kedua jenis data berdistribusi normal, maka selanjutnya dilakukan uji homogenitas varians (Levene Statistic). Hasil Uji Homogenitas disajikan dalam Tabel berikut.

Tabel 9 Hasil Uji Homogenitas N-Gain Kemampuan Berfikir Kreatif Kelas Eksperimen dan Kelas Kontrol

\begin{tabular}{ccc}
\hline No & Uji Statistik & P-Value \\
\hline 1 & F-Test & 0.234 \\
\hline
\end{tabular}

Berdasarkan Tabel 9 di atas, diketahui bahwa nilai P-Value sebesar 0.234, maka $0.234>0.05$ dengan demikian dapat disimpulkan bahwa data gain kedua kelas homogen. uji statistik selanjutnya adalah uji t. Hasil uji t disajikan dalam Tabel berikut.

Tabel 10 Hasil Uji Perbedaan Dua Rerata N-Gain Kemampuan Berfikir Kreatif Kelas Eksperimen Dan Kelas Kontrol

\begin{tabular}{ccc}
\hline No & Uji Statistik & P-Value \\
\hline 1 & t-tes & 0.000 \\
\hline
\end{tabular}

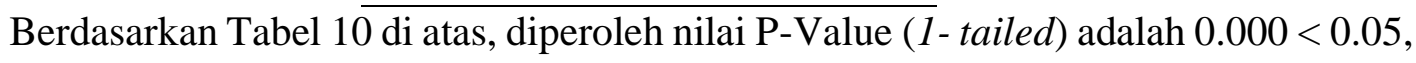
dengan demikian dapat disimpulkan bahwa peningkatan kemampuan berfikir kreatif pada kelas yang menggunakan pendekatan open-ended lebih tinggi daripada kelas yang menggunakan pembelajaran konvensioanal.

\section{Sikap Siswa terhadap Penerapan Pembelajaran dengan Pendekatan Open-Ended}

Secara umum, angket skala sikap yang dilakukan dalam penelitian ini memuat tiga indikator, yaitu (1) sikap yang menunjukan kesungguhan siswa saat pembelajaran matematika, (2) Sikap yang menunjukan minat siswa terhadap pembelajaran matematika, dan (3) Sikap siswa terhadap pembelajaran matematika yang menggunakan pendekatan open-ended. 
Setelah dianalisis secara deskriptif, skor kesungguhan siswa saat pembelajaran matematika memiliki rata-rata 3,03 dengan persentase sikap positif 64,08\% dan sikap negatif $35,92 \%$. Sikap yang menunjukan minat siswa terhadap pembelajaran matematika memiliki skor rata-rata 3,20 dengan persentase sikap positif 73,75\% dan sikap negatif sebesar 26,25\%. Sikap siswa terhadap pembelajaran matematika yang menggunakan pendekatan open-ended memiliki skor rata-rata 4,32 dengan persentase sikap positif sebesar 66,96\% dan sikap negatif sebesar $33,94 \%$. Data tersebut secara umum menunjukan bahwa siswa memiliki sikap positif terhadap penerapan pembelajaran dengan pendekatan open-ended.

\section{KESIMPULAN DAN SARAN}

Berdasarkan seluruh rangkaian penelitian yang telah dilakukan, mulai dari langkah persiapan, pelaksanaan, hingga analisis data, maka dapat dikemukaan kesimpulan sebagai berikut.

1. Peningkatan kemampuan berfikir kreatif siswa yang mendapatkan pembelajaran matematika dengan menggunakan pendekatan open-ended lebih tinggi dibandingkan dengan siswa yang mendapatkan pembelajaran konvensional.

2. Sebagian besar siswa memberikan sikap positif terhadap pembelajaran matematika yang menggunakan pendekatan open-ended.

Berdasarkan hasil penelitian dan kesimpulan mengenai pembelajaran matematika dengan menggunakan pendekatan pembelajaran Open-Ended, maka dapat diajukan beberapa saran sebagai berikut:

1. Pembelajaran matematika dengan menggunakan model pembelajaran Open-Ended untuk materi koordinat kartesius terbukti dapat meningkatkan kemampuan berpikir kreatif siswa dan mendapatkan sikap positif dari hampir seluruh siswa. Bagi peneliti yang ingin menggunakan model pembelajaran Open-Ended dapat mencoba menerapkan model Open-Ended pada materi lainnya serta pada aspek lainnya, seperti pengaruh model OpenEnded terhadap komunikasi matematika siswa.

2. Bagi setiap pengajar, setidaknya mampu mengembangkan kreatifitasnya dalam menyampaikan materi dan mengolah suatu jawaban dari soal sehingga dapat membangkitkan motivasi siswa dalam menyelasaikan soal.

3. Bagi peneliti selanjutnya sebaiknya mengadakan penelitian lebih awal agar lebih efektif dan mencari tempat penelitian yang berbeda guna untuk memperoleh hasil yang berbeda 
Penelitian ini membuktikan bahwa model pembelajaran Open-Ended dapat meningkatkan kemampuan berpikir kreatif siswa, maka dari itu guru dapat menjadikan model pembelajaran Open-Ended sebagai salah satu alternatif pembelajaran dalam meningkatkan kemampuan berpikir kreatif siswa. Selama proses pembelajaran hendaknya guru memperhatikan pengelolaan kelas sehingga siswa aktif ikut serta kegiatan belajar. Dalam pembelajaran Open-Ended motivasi dari guru sangatlah diperlukan agar siswa mampu mengungkapkan ide-ide dan gagasan-gagasan matematikanya, serta siswa menjadi lebih berani untuk menjelaskan materi kepada siswa lainnya.

\section{DAFTAR PUSTAKA}

Amalia, L. (2006). Penerapan pendekatan open ended untuk pencapaian berpikir kreatif. Skripsi FPMIPA UPI Bandung. Tidak diterbitkan

Bell, F. H. (1978). Teaching and Learning Mathematics (in secondary schools). United States: Brown Company Publisher.

Juarni, (2011). Pembelajaran matematika dengan menggunakan pendekatan open-ended untuk meningkatkan kemampuan berpikir kreatif. Skripsi STKIP Subang. Tidak diterbitkan

Lidya, S. (2009). Pembelajaran matematika dengan menggunakan pendekatan Open Ended untuk meningkatkan kemampuan berpikir kreatif siswa. STKIP Subang. Tidak diterbitkan

Maelis, S. (2009). Pembelajaran matematika dengan metode penemuan untuk meningkatkan kemampuan berpikir kreatif siswa. Skripsi STKIP Subang. Tidak diterbitkan

Rani, M. (2010). Model pembelajaran interaktif untuk pencapaian kemampuan berpikir kreatif. Skripsi STKIP Subang. Tidak diterbitkan

Ruseffendi, E. T (2010). Dasar-Dasar Penelitian Pendidikan \& Bidang Non-Eksata lainnya. Bandung: Tarsito

Sugiyono, (2012). Statistika untuk Penelitian. Bandung: Alfabeta

Suherman, Erman dkk. (2001). Strategi pembelajaran matematika kontemporer. JICA UPI Bandung.

Suharto, (2010). Pembelajaran dengan menggunakan pendekatan Open Ended untuk mencapai kemampuan komunikasi matematika siswa. Skripsi STKIP Subang. Tidak diterbitkan

Suherman, E. dkk. (2003). Strategi Pembelajaran Matematika Kontemporer. Bandung: JICA-UPI.

Sundayana, R. (2010). Statistika Penelitian Pendidikan. Garut: STKIP Garut Press.

Wahyudin. (2008). Pembelajaran dan Model-model Pembelajaran. Pelengkap untuk Meningkatkan Kompetensi Pedagogis Para Guru dan Calon Guru Profesional. Bandung: Tidak Diterbitkan.

zikra, (2006). kemampuan berpikir kreatifmateri persamaan kuadrat model creativeploblem solving siswa man 2 banda aceh (online) tersedia: https://repository.arraniry.ac.id/2640/1/NAZRATUL\%20ZIKRA.pdf (18juli 2019) 